\title{
EXPLORING RELATIONSHIPS BETWEEN KARST TERRAINS AND SOCIAL FEATURES BY THE EXAMPLE OF GÖMÖR-TORNA KARST (HUNGARY-SLOVAKIA)
}

\author{
RAZISKOVANJE ODNOSOV MED KRAŠKO POKRAJINO IN \\ SOCIALNIMI FUNKCIJAMI: PRIMER KRAŠKEGA OBMOČJA \\ GÖMÖR-TORNA (MADŽARSKA-SLOVAŠKA)
}

\author{
Tamás TELBISZ1 ${ }^{1}$ Zsolt BOTTLIK², László MARI ${ }^{3}$ \& Alena PETRVALSKÁ ${ }^{4}$
}

\begin{abstract}
UDC 911.5:551.435.8(439+437.6)
Tamás Telbisz, Zsolt Bottlik, László Mari \& Alena Petrvalská: Exploring Relationships Between Karst Terrains and Social Features by the Example of Gömör-Torna Karst (HungarySlovakia)

Human-environment relations have some special characteristics on karst terrains, and karstlands are usually less densely inhabited areas principally due to hydrologic, topographic and pedologic reasons. However, the natural factors of karst terrains and socio-economic development are rarely discussed together, and the relationships are usually expressed in qualitative terms. Therefore the aim of this paper is to explore the direct and indirect quantitative impact of natural settings on socio-economic development of karst terrains using GISaided, statistical methods as a modern approach within geographic possibilism by the case study of Gömör-Torna Karst (whose Hungarian part is known as Aggtelek Karst, while the Slovakian part as Slovak Karst). Relationships between natural factors (elevation, slope, relative height, distance from significant rivers) and land cover as well as between natural factors and social data (population density, settlement density, mean settlement population, population change, road network density) have been studied by regression analysis in order to determine how strongly these social parameters are influenced by the above natural factors. In certain cases (land cover categories, road network) slope is the best estimator, while in other cases (population density, longterm population change), the
\end{abstract}

\begin{abstract}
Izvleček
UDK 911.5:551.435.8(439+437.6)

Tamás Telbisz, Zsolt Bottlik, László Mari \& Alena Petrvalská: Raziskovanje odnosov med kraško pokrajino in socialnimi funkcijami: Primer kraškega območja Gömör-Torna (Madžarska-Slovaška)

Odnosi med človekom in okoljem imajo v primeru kraških okolij nekatere posebne značilnosti. Ta so običajno manj gosto naseljena predvsem zaradi hidroloških, topografskih in pedoloških posebnosti. Vendar pa je vpliv naravnih dejavnikov kraških pokrajin na družbeno-gospodarski razvoj redko proučevan, vplivi pa so običajno pojasnjeni v kvalitativnem smislu. Zato je cilj tega prispevka kot sodobnega pristopa znotraj geografskega posibilizma raziskati neposreden in posreden količinski vpliv obravnavanega naravnega okolja na družbeno-gospodarski razvoj z uporabo-GIS orodij in statističnih metod. Študija je bila opravljena na primeru kraškega območja Gömör-Torna (na Madžarskem znan kot kras Aggteleka oziroma na Slovaškem kot Slovaški kras). Razmerja med naravnimi dejavniki (nadmorska višina, naklon, relativna višina, oddaljenost od pomembnih rek) in pokrovnostjo tal, kot tudi med naravnimi dejavniki in socialnimi podatki (gostota prebivalstva, gostota poselitve, povprečno število prebivalcev v naselju, spremembe prebivalstva, gostota cestnega omrežja) smo proučevali z regresijsko analizo. Želeli smo ugotoviti, kako močno zgoraj navedeni naravni dejavniki vplivajo na socialne parametre. V nekaterih primerih (pokrovnost tal, cestno omrežje) je naklon najboljši pokazatelj, medtem ko v
\end{abstract}

\footnotetext{
${ }^{1}$ Department of Physical Geography Eötvös University, Budapest, Hungary, 1117 Budapest, Pázmány Péter sétány 1/C., e-mail: telbisztom@caesar.elte.hu

${ }^{2}$ Department of Regional Science, Geography Eötvös University, Budapest, Hungary, 1117 Budapest, Pázmány Péter sétány 1/C., e-mail: agria@gmx.net

${ }^{3}$ Department of Physical Geography Eötvös University, Budapest, Hungary, 1117 Budapest, Pázmány Péter sétány 1/C., e-mail:mari.laci@gmail.com

${ }^{4}$ Institute of Geography, University of Pavol Jozef Šafárik, Košice, Slovakia, Jesenná 5, Prirododevecká fakulta UPJS 04001 , e-mail: alena.petrvalska@upjs.sk
}

Received/Prejeto: 03.02.2013 
distance from significant river provides the best correlation. Many karstlands are depopulating and ageing areas worldwide. So is the case for the Gömör-Torna Karst as well, but there are several interesting questions in connection with it. First, whether it is a recent process or a longterm situation. Second, wether the karst is different from the neighbouring non-karst areas from the viewpoint of demography. Third, whether the karst area is homogeneous from social point of view. Cluster analysis based on demographic changes since 1828 helped to explore inner variations of population scenarios. Certain social characteristics (e.g. unemployment) show a relatively (but only relatively) favorable present position of Aggtelek karst, while the Slovak Karst is economically more disadvantageous. Karstrelated tourism is measurable but it has a decreasing trend and it is rather localized around Aggtelek. Human attitude is also an important factor, that is also briefly discussed based on semi-structured interviews with local people.

Keywords: human-environment relations, GIS, possibilism, Aggtelek Karst, Slovak Karst, tourism drugih primerih (gostota prebivalstva, dolgotrajne spremembe prebivalstva) najboljšo korelacijo zagotavlja oddaljenost od večje reke. Veliko kraških območij po vsem svetu se sooča $\mathrm{z}$ zmanjševanjem števila in s staranjem prebivalstva. Prav tak je primer kraškega območja Gömör-Torna, vendar pa ta primer sproža še številna druga zanimiva vprašanja. Kot prvo nas zanima, ali gre za trenuten proces ali za dolgoročno situacijo. Drugič, ali do demografskih sprememb prihaja zaradi razlik med kraškimi in sosednjimi nekraškimi območji. Tretjič, ali je proučevano kraško območje homogeno z družbenega vidika. Klastrska analiza, ki temelji na demografskih spremembah od leta 1828 , je pomagala raziskati notranje spremembe sestave prebivalstva. Nekatere socialne značilnosti (na primer brezposelnost) kažejo relativno (ampak samo relativno) ugoden trenutni položaj krasa Aggtelek, medtem ko je Slovaški kras ekonomsko manj ugoden. Turizem, vezan na kras, je merljiv, vendar ima negativen trend in je precej lokaliziran okrog Aggteleka. Človekov odnos je prav tako pomemben dejavnik, kar prav tako na kratko razpravljamo na podlagi polstrukturiranih intervjujev z lokalnim prebivalstvom.

Ključne besede: odnosi človek-okolje, GIS, posibilizem, kras Aggtelek, Slovaški kras, turizem.

\section{INTRODUCTION: THE KARST AND SOCIETY CONTEXT}

Karst terrains have characteristic morphological, hydrological, pedological and ecological features. These characteristics impact socio-economic development in a number of ways. One of the basic questions in geography is to what extent are the social parameters influenced by environmental settings (e.g. Harden 2012). Although formerly and occasionally even now, extreme views are articulated in connection with this question (e.g. determinism, nihilism, constructivism), we think that the approach of possibilism provides the right way, which states that the impact can not be questioned, but its scale and its ways can be different that is worth for being studied (these thoughts are reviewed e.g. in Köszegi et al. 2015). The American geographer, Sauer C. emphasized that human behaviour is not dependent solely on environmental constrains and by rejecting positivism he favoured the study of small territorial units, what he called „cultural landscapes", expressing that they are the results of the joint influence of culture and nature (Harden 2012). On the contrary, today's research focus rather on global issues and up-to-date GIS-methodology opens up new opportunities to examine human-environment relationships in quantitative terms. An interesting approach of this kind is hypsographic demography, which explores how demographic parameters change according to relief categories (e.g. Cohen \& Small 1998; Meybeck et al.
2001; Patterson \& Doyle 2011). We think that it is also worthwile to explore and check the validity of quantitative relationships in smaller scales. This idea is present in some, but not too many previous studies (e.g. Song et al. 2007; Milošević et al. 2010, 2011). In a previous work, we also applied this approach to the country of Montenegro whose $2 / 3$ is karst terrain (Telbisz et al. 2014). Thus, the aim of this study is to investigate human-environment relationships in quantitative terms by the case example of a smaller territory, namely the Gömör-Torna (Gemer-Turňa) Karst (whose Hungarian part is known as Aggtelek Karst, and the Slovakian part as Slovak Karst).

In fact, the relationship of the karst-geo-ecosystem and the society is two-way. Karst terrains are vulnerable to environmental disturbances due to their high hydrologic permeability and shallow soils (e.g. Bárány-Kevei 1998; Zhang et al. 2003; Parise et al. 2009; Keveiné 2014). The environmental problems are in many cases karstspecific and their management and the mitigation of natural hazards require the knowledge of karst processes (e.g. Gutierrez et al. 2014). Nevertheless, in this paper, we do not consider the human impact on karst, instead, we study the positive and negative effects of karst exerted on humans living on karst terrains. We try to understand how much the karst modifies the possibilities of socioeconomic development and the ways of life on karst. 
Here we note however, that this impact is in most cases indirect.

As Day (2010) stated: „karstlands are challenging to human habitation", that is karsts imply more difficulties than possibilities to their people. As for the agriculture, karst terrains usually have low potential (Ravbar 2004). The formation and development of settlements on karst have been studied by several authors (e.g. Móga 1998; Lovász \& Gyenizse 2012). Fürst-Bjeliš et al. (2001) and Pejnović and Husanović-Pejnović (2008) focussed mainly on demographic changes, which occurred in the characteristic karst landscape of Velebit Mountains during the recent centuries. They emphasized the relationship of land use and karst relief types. Ballut and Faivre (2012) seeked correlations between these demographic processes and sediments preserved in doline traps. Ravbar (2004) analyzed the possibilities of karst water management by the example of the Classical Kras plateau. Erjavec and Peršić (2005) presented an interesting microscale study, in which they explored the typical way of life of people living around intermittent karstic lakes. Further on, it is obvious that karst terrains require special approach during hydrologic engineering (Milanovic 2002) and road construction (Knez \& Slabe 2010). Summing up the above papers, it is concluded that in most cases, karst landscapes are characterized by lower development, higher unemployment and emigration, thus, in order to advance the (sustainable) development of karst areas, attention and definite measures are needed, as it was argued by Maleković et al. (2010) considering the situation of Velebit region.

On the other hand, beside the above-mentioned, mostly disadvantegeous features, it is also necessary to emphasize the „heritage dimension” (e.g. Kiernan 2011). Naturally, the most important of them is the geo-heritage, the caves and the typical karst landforms. However, some authors distinctly describe the notion of „hydrological heritage" and they argue for protecting it (Simić et al. 2014). Others mention the karst-related cultural heritage, which can be either of religious type (Barbosa \& Travassos 2008), or the preservation of the traditional way of life that is due to the remoteness or enclosedness of certain karst terrains (Kiernan 2011). This heritage dimension is really valuable nowadays that is reflected by the fact that several karst features have become part of the World Heritage. Today, this value can be transformed into economic benefit mainly by tourism. However, tourism may also result serious problems, thus, good practices and management are crucial (e.g. Zhang et al. 2003; Duval 2006; Mao et al. 2014).

In this paper, our intention is to find statistical relationships between basic natural and social factors and to explore how much the above social phenomena (lower development, depopulation, growing tourism) typical of karst terrains worldwhile are valid for the Gömör-Torna Karst. Our study area is particularly interesting because its cave systems together (i.e. independent from the state boundary) are a part of the World Heritage that provides possibilities for cross-border cooperations. As for the methodology, we use mostly GIS-analysis and the experiences collected during field trips as well as semi-structured interviews. An essential principle of our analysis was that we took into consideration the neighbouring non-karstic areas in order to discriminate which effects are karst-related and which effects are rather due to local social processes.

\section{STUDY AREA}

The Gömör-Torna Karst (GTK in the followings) is found in the northeastern part of Hungary and southeastern part of Slovakia. Topographically it is a transitional terrain with low mountains and hills between the higher Rudohorie Mts (part of the Carpathians) and Putnok and Cserehát Hills lowering towards the Great Plains of Hungary (for a detailed presentation of this large-scale topography see Telbisz 2011 and references therein). Among the cave systems being together in the World Heritage list, the longest one is the $25 \mathrm{~km}$ long Domica-Baradla system nearby Aggtelek. A speciality of this cave is that its main passage crosses the state border. The geomorphology of GTK is characterized by several karst plateaus with me- dium density of dolines (1-30 dolines $/ \mathrm{km}^{2}$ depending on the plateau), dissecting river valleys and small basins.

The whole study area (Fig. 1) includes the territory between Sajó (Slaná)-Muráň and Hernád (Hornád) rivers and the southern part of Rudohorie Mts. Taking into considerations topographic, geologic and hydrologic settings as well as the already existing landscape division (Dövényi 2010) we distributed the study area into 8 units and these units (landscapes) are the basic elements of our analysis (Fig. 2, Tab. 1). These are the followings (Id numbers in brackets are used later on in this paper): Rudohorie Mts (only the southern part is included in this study; 1), Rudohorie Foothills (2), Northern valleys \& 




Fig. 1: Location of the study area.

basins (3), GTK (4), Cserehát Hills (5), Szendrő Hills (6), Putnok Hills (7) and Southern valleys \& basins (8).

Inhabitation of the karst area in the Middle Ages was a slow process with respect to the neighbouring lower terrains and it progressed mainly along the river valleys during the $10^{\text {th }}-13^{\text {th }}$ centuries. Wars and epidemics of the $16^{\text {th }}-18^{\text {th }}$ centuries decimated the population and some villages (e.g. Aggtelek) were even totally deserted (Dobány 2010b). Although the second half of the 19th century brought prosperity in Austria-Hungary, this boom was very limited in the study area. The new political border after the 1st World War cut this territory, thus many economic linkages were cancelled. As a consequence, the karst terrain, especially in the Hungarian side, became a borderland isolated from the main traffic. This isolation started to dissolve only after the 1990 change of regime. Now, as both countries joined the EU, the linkages are getting restored. At present, the study terrain encompasses 249 settlements with 244454 people on an area of $3781 \mathrm{~km}^{2}$.

There is a wide range of publications concerning the study area dealing with either natural or social issues, however, the integrated study of the whole karst terrain was not typical during most part of the $20^{\text {th }}$ century because of the political border. Here, we mention some works, which analyze the human-environment relationships as well, approaching them either from the natural settings (Szabó 1984; Mezősi 1998; Telbisz et al. 2013, 2014) or from the social conditions (Beluszky 1979) or from a historical geographical viewpoint (Dénes 1998; Móga 1998; Dobány 2010a, 2010b).

\section{DATA AND METHODS}

In order to study human-environment relationships we took into consideration the following natural factors: geology, topography, hydrography and land cover. In fact, the land cover is only partially natural, because it is strongly influenced by anthropogenic factors. Geologic maps were used to help the delineation of landscapes 


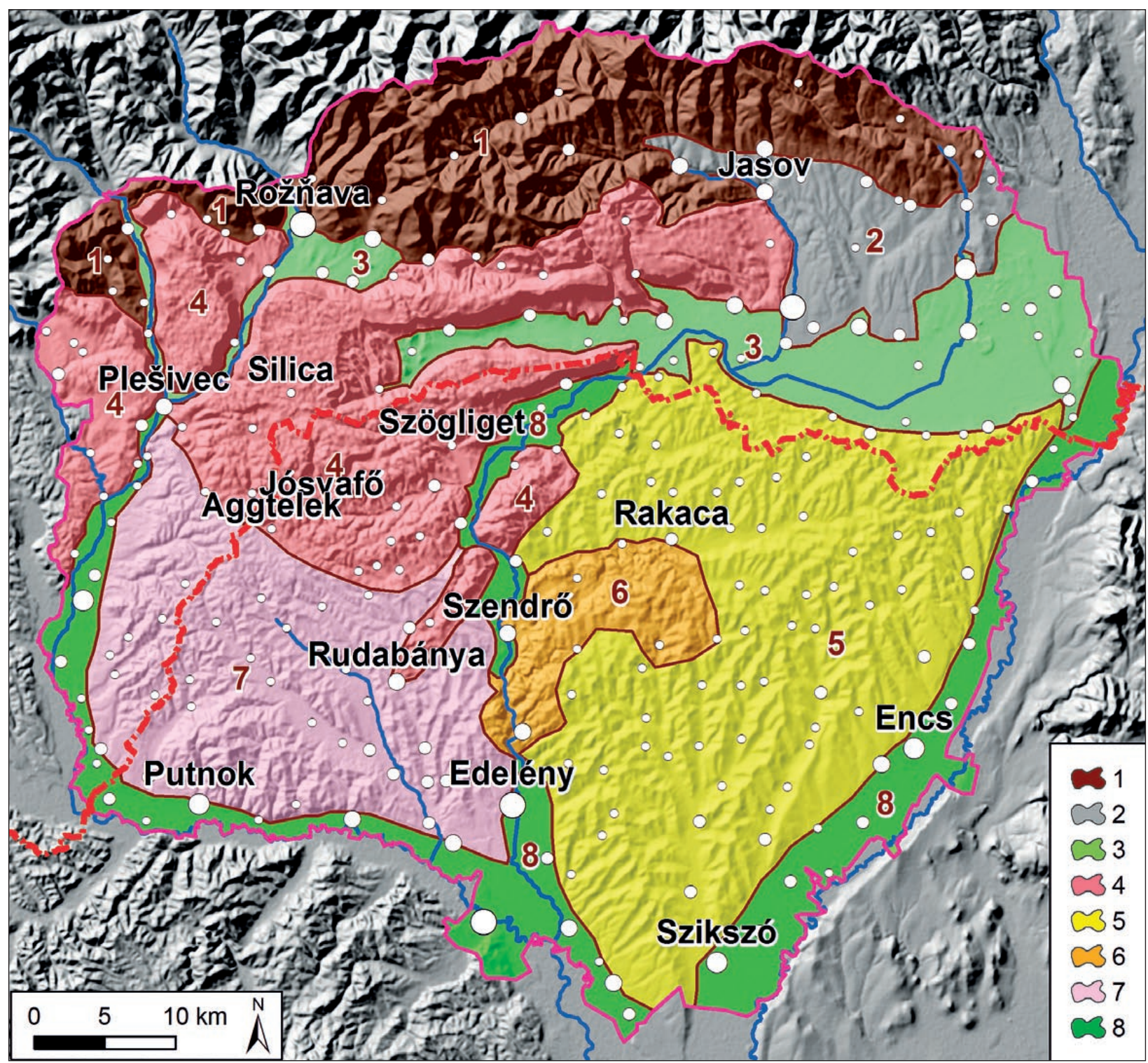

Fig. 2: Landscape units of the study area. 1: Rudohorie Mts; 2: Rudohorie Foothills; 3: Northern Valleys \& Basins; 4: GTK; 5: Cserehát Hills; 6: Szendrö Hills; 7: Putnok Hills; 8: Southern Valleys \& Basins.

and to determine their surficial lithological composition. Relief characteristics (elevation a.s.l., slope, relative height) were computed from the 3" SRTM digital terrain dataset, which is an almost global digital elevation model recorded by interferometric synthetic aperture radar (for further details see e.g. Rabus et al. 2003). Its circa $90 \mathrm{~m}$ horizontal resolution is appropriate for our study, but it is noted that due to its medium resolution, the real slopes are somewhat higher than the values calculated from SRTM. Relative height (further on we use only the word „height”) is defined as the elevation difference between the actual point and the lowermost point of its neighbourhood. In the present study we used a $4.5 \mathrm{~km}$ radius neighbourhood that was adjusted to the typical valley width of the study area. In order to characterize the accessibility of a given point, we took into consideration another natural parameter, the distance to the nearest significant river („,river distance" in the followings). Naturally, the word „significant" is valid only in a local context. We selected those rivers as significant, whose valleys were suitable for the construction of higher order roads and railways without topographic obstacles. Land cover data originated from the Corine CLC2006 database.

As for social data, we took into consideration the settlement locations, the road network and the popu- 
lation statistics from 1828 to 2011 at circa 20 year increments. The present demographic situation was characterized by the proportion of people aged 60 or over. Beside the above basic parameters, we used some settlement scale indicators to seize the actual state of social development (e.g. unemployment rate, number of guest nights, bus services to local centres). For population statistics, we used historical statistics volumes (Nagy 1828; Fényes 1851; Jékelfalussy 1892; Majtán 1978; Csorba 1991; Kepecs 1995, 1996; Turkovics 1996; Zentai 2001; Barsi 2004) as well as data of population censii (1870-) which started in Hungary in the last third of the 19th century, and population census data of Czechoslovakia (1920-93) and Slovakia (1993-). „Present" data refer to the last population census in 2011. We also used k-means type cluster analysis of settlement demographic changes in order to explore typical population scenarios in the study area. Population changes in percent were calculated for each 20 year step for each settlement and these data were the input to the cluster analysis.

Other social data (proportion of people older than 60 , commercial accomodation nights, unemployment ratio, ethnicity) were collected from the Hungarian Central Statistical Office and the Statistical Office of the Slovak Republic. Field work was carried out to get a general overview about the state and problems of settlements and to interview local people. The aim of the interviews was not a statistical analysis but to explore the present situation and recent changes in the way of life of local people. Altogether, 30 interviews were done (including interviews with 4 mayors, 1 priest, 2 entrepreneurs, 2 teachers among others).

In the GIS-analysis we used both raster and vector based operations. As social data are basically assigned to points (settlements) and polygons (full area of settlements) we adjusted the naturally delineated study area borders to the boundaries of settlements.

In our previous analysis (Telbisz et al. 2014) we explored relationships of environmental and social parameters on the settlement scale. However, given the many particular situations, we found a scattering of data and relationships were usually weak, though statistically significant. Thus, in order to better recognize theoretical relationships now we focus our analysis on the landscape scale (and we mention results of settlement scale analysis only in a few exceptions). Here we note that using 8 units (landscapes) in regression analysis means that the relationships are statistically significant at the 95\% confidence level if the correlation coefficient $(r)$ is greater than 0.6319 , that is the determination coefficient $\left(r^{2}\right)$ is greater than 0.3993. In the regression analysis we selected the best-fit functions, which were in most cases nonlinear functions.

Since the aim of our study is to statistically evaluate the general linkages between karst terrains and society, there is no place here to articulate details and analyze special cases and deviations, even if these are interesting issues, too.

\section{RESULTS AND DISCUSSION}

\section{BASIC LANDSCAPE CHARACTERISTICS}

The main characteristics of the natural settings are found in Tab. 1. The elevation histograms (Fig. 3) demonstrate that the Rudohorie Mts (1) form the highest terrain within the study area with a stretched maximum frequency at elevations between circa 400 and $700 \mathrm{~m}$. The GTK (4) is the second highest in elevation with a smaller frequency maximum at circa $500 \mathrm{~m}$ and a larger maximum at around $250 \mathrm{~m}$. All other landscapes have much lower elevation maxima and much lower ranges of elevation.

Slope histograms testify the dissected character of Rudohorie Mts, but it is remarkable that GTK has higher frequencies in the steepest $\left(>25^{\circ}\right)$ slope categories than Rudohorie Mts. It is a typical phenomenon that karst landscapes have relatively high frequencies in both low and „extreme" high slope classes. However, the mean slope of GTK is significantly lower than that of Rudohorie Mts.

At first, we checked the hypothesis that karst terrains are usually relatively rarely inhabited landscapes. For the GTK, we got that it is really the least densely populated landscape $\left(18.2 \mathrm{p} / \mathrm{km}^{2}\right)$ within the study area (see Tab. 1). This value was calculated for the whole GTK area, which includes the settlements found at the feet of karst plateaus even if they are located on non-karstic (basically on Quaternary fluvial) rocks. If we use strictly the superficial area of karstifiable rocks, there are only 5 settlements and the calculated population density is as low as $2.2 \mathrm{p} / \mathrm{km}^{2}$. However, by computing population densities for buffer zones around the strictly defined karst, we found the highest density, $111 \mathrm{p} / \mathrm{km}^{2}$, in the $250-500 \mathrm{~m}$ distance zone and decreasing values as distance grows. It proves that although the population density of karst 


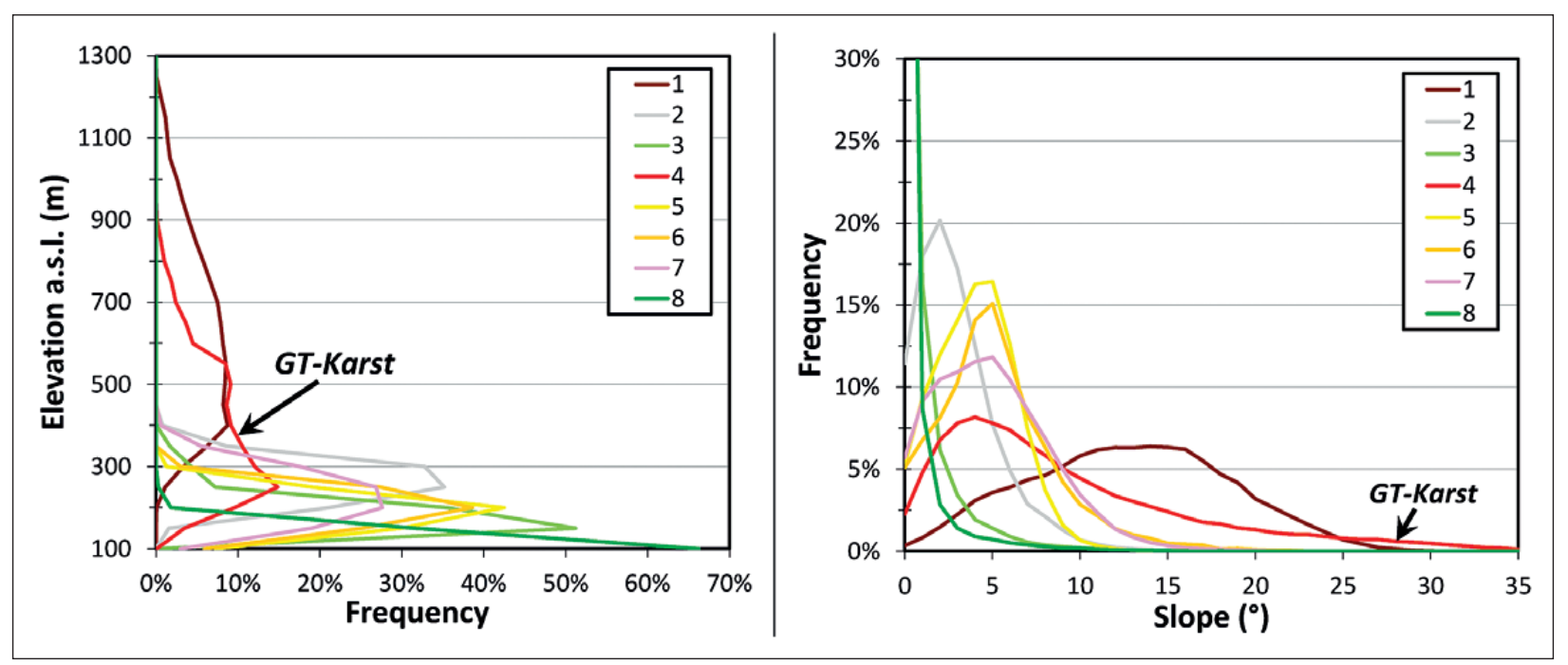

Fig. 3: Elevation and slope histograms by landscapes.

Tab. 1: Basic natural and social data of the studied landscapes.

\begin{tabular}{|c|c|c|c|c|c|c|c|c|}
\hline $\begin{array}{l}\text { Landscape } \\
\text { name }\end{array}$ & Rudohorie Mts & $\begin{array}{l}\text { Rudohorie } \\
\text { Foothills }\end{array}$ & $\begin{array}{c}\text { Northern } \\
\text { Valleys \& } \\
\text { Basins }\end{array}$ & $\begin{array}{c}\text { Gömör- } \\
\text { Torna Karst } \\
\text { (GTK) }\end{array}$ & Cserehát Hills & Szendrö Hills & Putnok Hills & $\begin{array}{c}\text { Southern } \\
\text { Valleys \& } \\
\text { Basins }\end{array}$ \\
\hline Id & 1 & 2 & 3 & 4 & 5 & 6 & 7 & 8 \\
\hline Area $\left(\mathrm{km}^{2}\right)$ & 528 & 164 & 338 & 770 & 923 & 125 & 526 & 402 \\
\hline $\begin{array}{l}\text { Dominant } \\
\text { lithology }\end{array}$ & Metamorphic & $\begin{array}{c}\text { Pre- } \\
\text { Quaternary } \\
\text { Sedimentary }\end{array}$ & $\begin{array}{c}\text { Quaternary } \\
\text { Fluvial }\end{array}$ & Limestone & $\begin{array}{l}\text { Quaternary } \\
\text { Sedimentary }\end{array}$ & $\begin{array}{l}\text { Quaternary } \\
\text { Sedimentary; } \\
\text { Metamorphic }\end{array}$ & $\begin{array}{c}\text { Neogene- } \\
\text { Quaternary } \\
\text { Sedimentary }\end{array}$ & $\begin{array}{c}\text { Quaternary } \\
\text { Fluvial }\end{array}$ \\
\hline $\begin{array}{l}\text { Mean elevation } \\
\text { a.s.l. }(\mathrm{m})\end{array}$ & 656 & 288 & 214 & 423 & 214 & 224 & 253 & 142 \\
\hline Mean slope $\left({ }^{\circ}\right)$ & 13.3 & 3.5 & 1.2 & 9.8 & 4.6 & 5.8 & 5.5 & 0.8 \\
\hline No. settlements & 19 & 14 & 34 & 37 & 64 & 7 & 31 & 43 \\
\hline Population & 12458 & 26853 & 55818 & 14025 & 22501 & 3132 & 20599 & 89068 \\
\hline $\begin{array}{l}\text { Settlement } \\
\text { density } \\
\left(1 / 1000 \mathrm{~km}^{2}\right)\end{array}$ & 10.0 & 2.3 & 11.5 & 28.5 & 59.3 & 0.9 & 16.3 & 17.4 \\
\hline $\begin{array}{l}\text { Mean } \\
\text { settlement } \\
\text { population }\end{array}$ & 656 & 1918 & 1642 & 379 & 352 & 447 & 664 & 2071 \\
\hline $\begin{array}{l}\text { Population } \\
\text { density }\left(1 / \mathrm{km}^{2}\right)\end{array}$ & 23.6 & 164.0 & 165.2 & 18.2 & 24.3 & 24.9 & 39.1 & 219.8 \\
\hline $\begin{array}{l}\text { Road density } \\
\left(\mathrm{km} / \mathrm{km}^{2}\right)\end{array}$ & 0.24 & 0.41 & 0.55 & 0.27 & 0.34 & 0.30 & 0.34 & 0.38 \\
\hline $\begin{array}{l}\text { Population } \\
\text { change } \\
\text { between } 1828 \\
\text { and } 2011\end{array}$ & $-21.9 \%$ & $63.9 \%$ & $76.3 \%$ & $-28.0 \%$ & $-36.4 \%$ & $-23.2 \%$ & $50.8 \%$ & $91.4 \%$ \\
\hline
\end{tabular}

may be low, but near its edges, the natural settings provide favorable conditions to the formation of settlements (Fig. 4).

\section{REGRESSION ANALYSIS}

Here we present the statistical strength of relationships between landscape mean values of elevation, slope, height, river distance and mean values of social or land use parameters (Tab. 2). For each parameter we plot the graph of the strongest relationship and in order to measure the special effect of karst, we examine the deviation of GTK from the regression curve (Fig. 5).

First, it is observed that settlement density is not correlated with any of the studied natural factors. GTK 


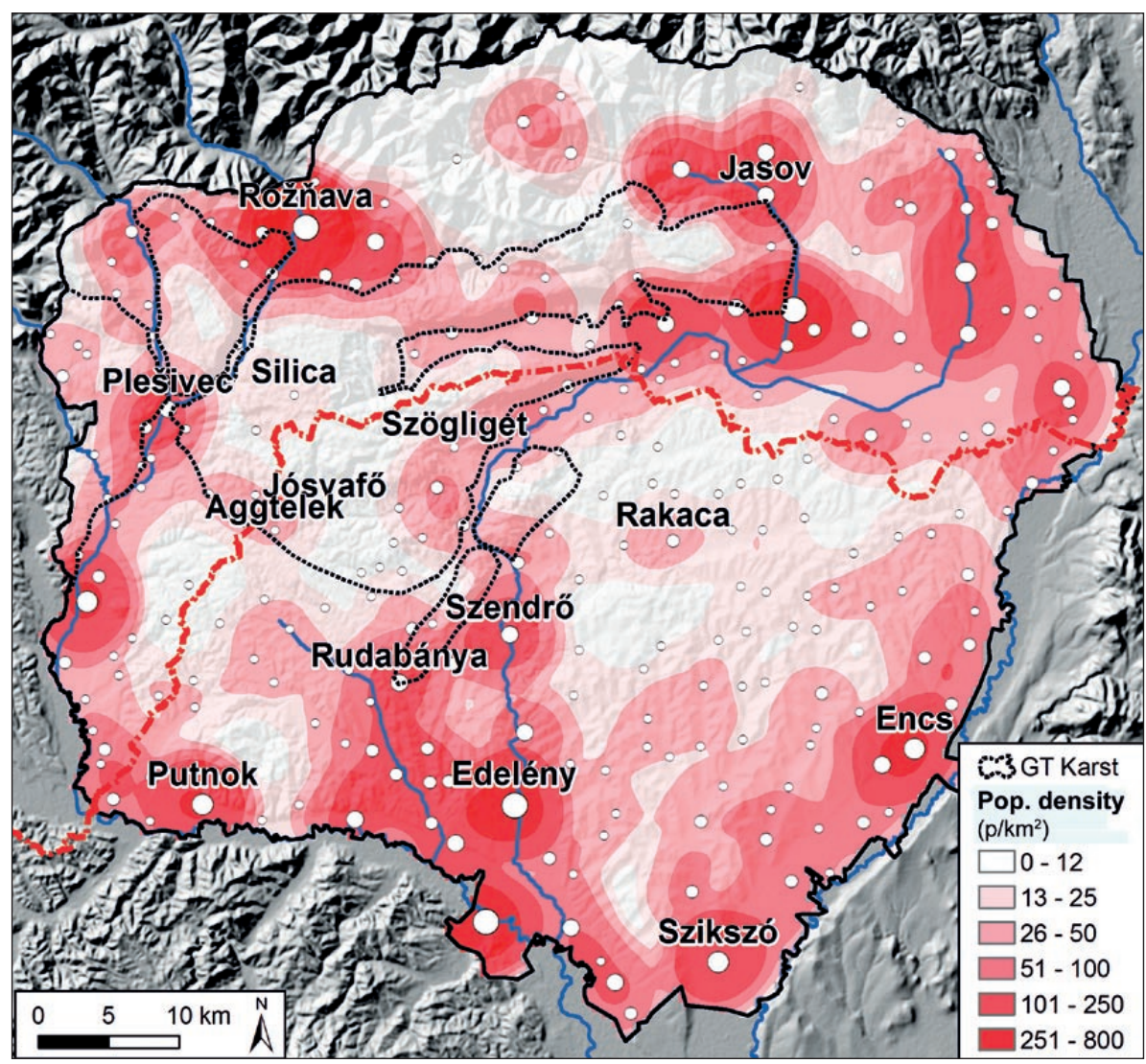

Fig. 4: Population density of the study area calculated by Kernel algorithm.

Tab. 2: Determination coefficients $\left(r^{2}\right)$ of the studied relationships (d-decreasing function; bold: highest $r^{2}$ ).

\begin{tabular}{l|c|c|c|c|c}
\hline \multirow{2}{*}{ Dependent variable } & \multirow{2}{*}{ Best-fit function } & \multicolumn{4}{|c}{ Independent variable } \\
\cline { 3 - 6 } & & Elevation & Slope & Height & River distance \\
\hline Settle. density & linear & 0.018 & 0.00003 & 0.0011 & 0.1409 \\
\hline Mean population & logarithmic (d) & 0.2024 & 0.6494 & 0.5132 & 0.7657 \\
\hline Pop. density & logarithmic (d) & 0.3232 & 0.7958 & 0.6663 & 0.8119 \\
\hline Artificial & power (d) & 0.5083 & 0.9116 & 0.8051 & 0.6751 \\
\hline Agricultural & exponential (d) & 0.7506 & 0.9379 & 0.8647 & 0.3806 \\
\hline Pasture & exponential & 0.0099 & 0.0577 & 0.0086 & 0.1341 \\
\hline Forest & logarithmic & 0.7515 & 0.9096 & 0.89 & 0.5532 \\
\hline Grass \& shrub & logarithmic & 0.4439 & 0.7698 & 0.6589 & 0.6543 \\
\hline Road density & exponential (d) & 0.4698 & 0.7713 & 0.6473 & 0.4388 \\
\hline Pop.change (1828 to 2011) & logarithmic (d) & 0.291 & 0.6594 & 0.5461 & 0.8628 \\
\hline
\end{tabular}

has the second highest value ( 28.5 settlements $/ 1000 \mathrm{~km}^{2}$ ) after Cserehát Hills (see Tab. 1). While the settlement density is high, the mean settlement population is low. This latter parameter shows significant correlation with river distance (and also with slope and height). Looking at the regression curve, it is obvious that GTK settlements have even less people than it could be estimated from this curve. Population density significantly depends on the same factors (i.e. river distance, slope, height) and GTK is again below the regression curve. Briefly, the GTK is a landscape with high density of tiny villages, where the settlements are concentrated at the feet of karst plateaus.

As for the land cover, it is demonstrated that practically all of the main components (forest, agriculture, grass \& shrub, artificial; except pasture) are in close correlationship with slope, and the relationships are significant with the other natural factors as well. In each case, the GTK fits the regression curve that means that the direct effect of karst is neglectable in the present land cover distribution (Fig. 6), instead the topographic impact is the dominant. 


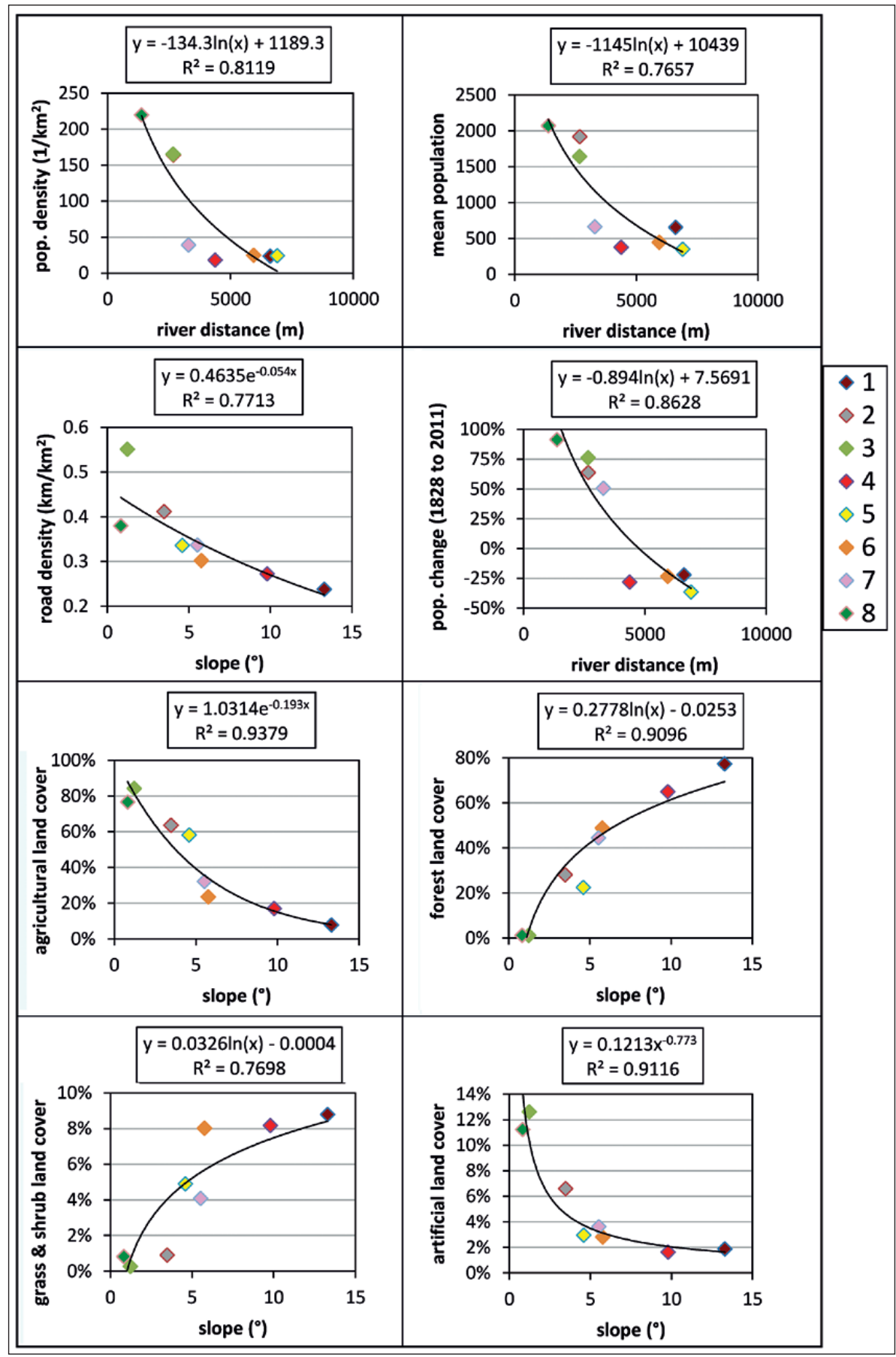

Fig. 5: Functional relationships between physical parameters and land cover or social parameters

(GTK is red in each diagram). 1: Rudohorie Mts; 2: Rudohorie Foothills; 3: Northern Valleys \& Basins; 4: GTK; 5: Cserehát Hills; 6: Szendrö Hills; 7: Putnok Hills; 8: Southern Valleys \& Basins.

Among social data, the road density can be best estimated by slope, however it is in significant relationship with all other physical factors, too. Again, GTK does not deviate from the regression curve, thus, in this case, the slightly lower density road network of the karst can be explained by topographic factors only and the direct effect of karst can not be measured.

The longterm (1828 to 2011) population change has the strongest relationship with river distance, and its correlations with slope and height are also significant. This value discriminates well the winners and losers in the longterm, and as the GTK is below the regression curve the karst are among the losers in this context and the longterm negative population change here was even higher than it could be calculated from the mean river distance (i.e. low accessibility).

In order to evaluate whether river distance can be used as an estimator of low accessibility („remoteness”) 


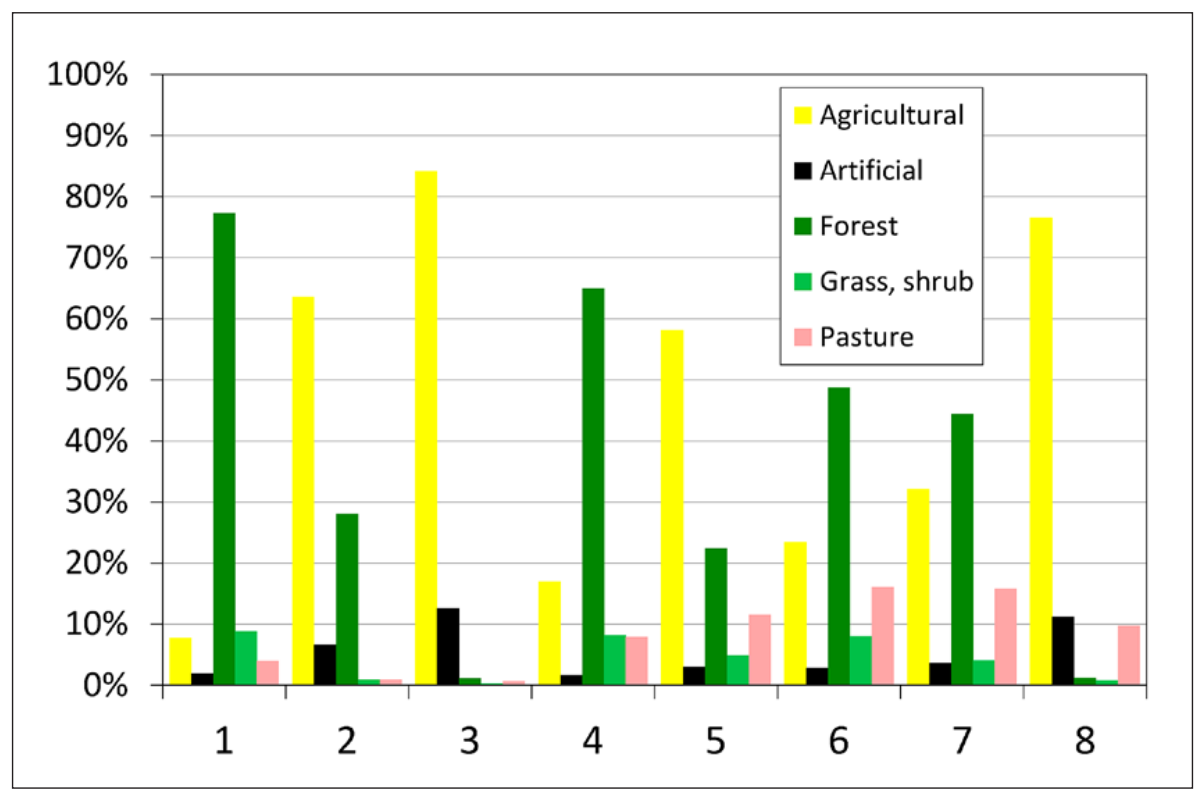

Fig. 6: Main (>1\% proportion) land cover categories of the studied landscapes.

of settlements, we analyzed bus lines to the local centres (only for the Hungarian part). As a result, we got a weak but statistically significant relationship ( $r=-0.45$; taking into consideration 92 settlements in this analysis) between the number of bus departures to local centres and river distance.

\section{DEMOGRAPHIC PROCESSES}

Demographic changes since 1828 can be seen in Fig. 7 . Even at the beginning of the studied period, the more or less plain and the hilly-mountainuous landscapes had different population densities but the differences have been highly increased since then. The zoomed in right part of Fig. 7 shows that even in the $19^{\text {th }}$ century the hilly landscapes could be characterized by stagnation or occasionally by decrease. The only exception was the Putnok Hills (7), where coal mining and the industrialization of nearby areas stimulated a locally significant population growth. After a weak increase in the first half of the $20^{\text {th }}$ century, there was a serious decline of population in all hilly and mountainuous areas especially after 1970 . However, after the change of regime in 1990, the decrease was stopped in some landscapes due to the inflow and higher reproduction rate of Roma people. The GTK was the least densely populated area from the beginnings with values similar to the Rudohorie Mts and a not yet finished decline at the turn of the $21^{\text {st }}$ century.

We were curious to know if landscapes are homogeneous or heterogeneous from the viewpoint of population changes, this is why we applied the cluster analysis in order to find typical demographic scenarios. From Fig. 8 it is clearly seen, that population changes up to the middle of the $20^{\text {th }}$ century were small and relatively simi- lar in the whole study area and that clusters differ from each other mainly in their post $2^{\text {nd }}$ world war trends. We got the following, well interpretable clusters (Fig. 8):

Cluster 1) These settlements had higher population growth during the whole period except the last phase. There was a relative prosperity after the $2^{\text {nd }}$ World War, but the growth became slower from 1970 and finally it has stopped. This scenario is typical of the settlements of the larger valleys and basins.

Cluster 2) It is marked by low growth rate and occasionally negative growth during the $19^{\text {th }}$ century, a prosperity up to 1970 and a decline afterwards. However, after the change of regime in 1990 there has been a significant increase - the only cluster where it is typical. In most cases this can be linked to the sudden growth of Roma population. In several rural settlements they live in slum-like conditions. This history is characteristic mainly in the eastern part of GTK, especially in Slovakia.

Cluster 3) It can be characterized by medium population changes within the study area, that is a low growth rate in the first part of the examined period. In this cluster there was no prosperity at all in the $20^{\text {th }}$ century, however, the decline occurred and the population largely diminished after the change of regime. This scenario is typical in GTK and in the inner parts of the hills but not in the most hidden villages.

Cluster 4) It is very similar to cluster 3 , but the rate of decline was slightly lower and these settlements could stabilize their population after the change of regime. Typically these are small local centres or villages, which are easily accessible from larger central settlements. Aggtelek, the village that gave its name to the National Park 


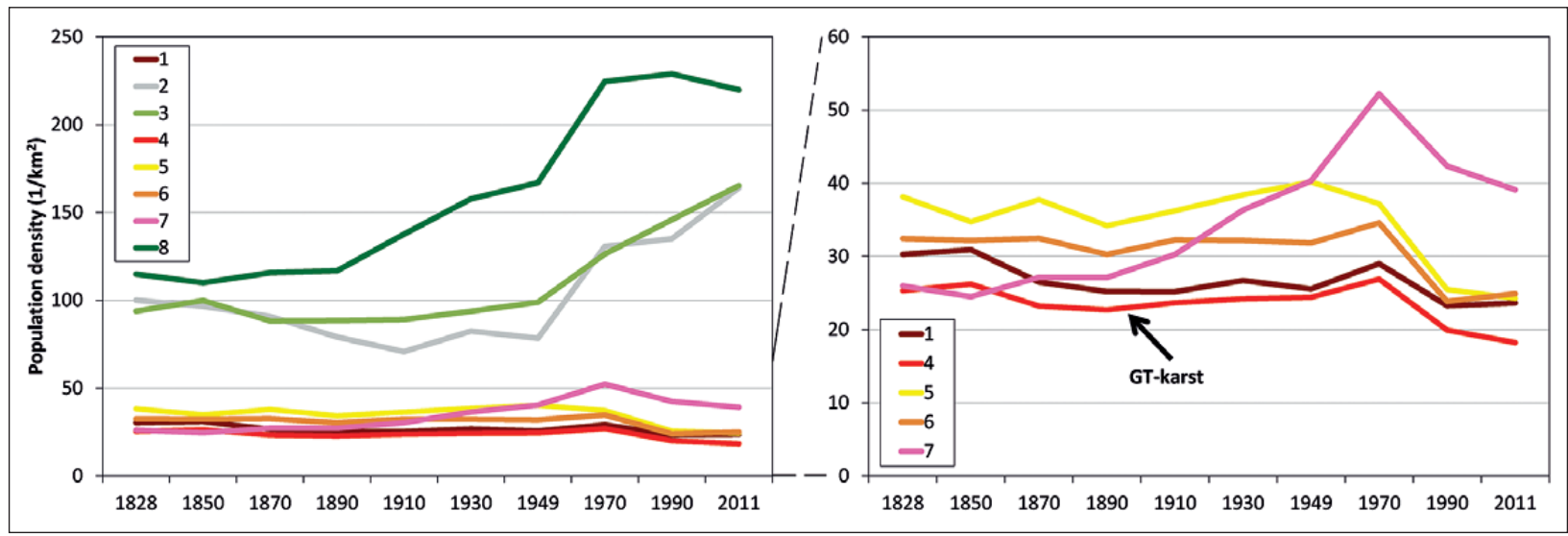

Fig. 7: Population density changes since 1828. Left: all landscapes, right: only the less densely inhabited landscapes.

and to the karst landscape is also in this group. That is certainly due to its tourism potential as the most famous Hungarian cave, the Baradla cave is found here. However it is striking that Aggtelek in spite of being the number one karstic tourist destination could only avoid a stronger decline, but could not preserve (or increase) its former population.

Cluster 5) It is the most disadvantageous from demographic viewpoint, characterized by decrease during most part of the studied period and with a strong and continuous decline since the middle of the $20^{\text {th }}$ century. These are the most enclosed settlements. Although the construction of roads have no insurmountable physical barriers here, but there is an absolute lack of transit paths even at the smallest scale. A significant part of these settlements are dead-end villages. Many of them became dead-end due to the change of political border in 1920 and their declining situation was conserved by the development policy of the 1970s, too. These settlements are situated in the central parts of the GTK and in the Cserehát and Szendrö Hills at traffic shadow positions. Several of them are now at the verge of extinction with only dozens of elderly inhabitants.

Summing up the above results, it is stated that demographic scenarios are neither independent from nor determined by natural landscapes, and there are several variations within each landscape that can be captured by cluster analysis.

A consequence of the above demographic processes can be observed in the age structure of popula-

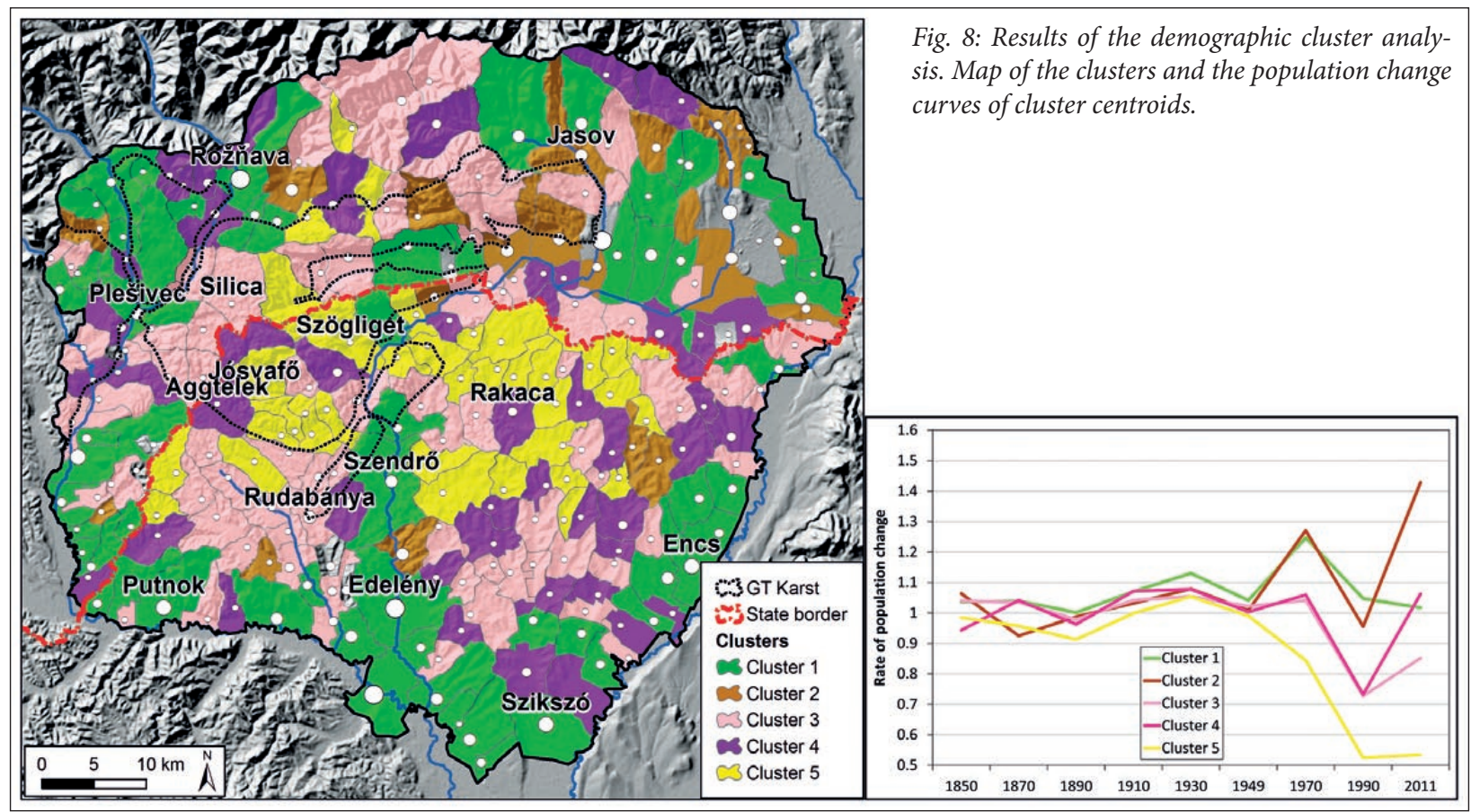


Tab. 3: Some social data (for year 2011) of the study area. SL: Slovakian part; HU: Hungarian part; no: no settlements in the given category.

\begin{tabular}{l|c|c|c|c|c|c|c|c}
\hline \multirow{2}{*}{$\begin{array}{l}\text { Landscape } \\
\text { Id }\end{array}$} & \multicolumn{2}{|c|}{$\begin{array}{c}\text { Mean proportion of 60+ } \\
\text { people }\end{array}$} & \multicolumn{2}{c|}{$\begin{array}{c}\text { Mean rate of } \\
\text { unemployment }\end{array}$} & \multicolumn{2}{c|}{ Accomodation nights } & \multicolumn{2}{l}{ Mean ratio of Roma people } \\
\cline { 2 - 11 } & $S L$ & HU & SL & HU & SL & HU & SL & HU \\
\hline 1 & $20.8 \%$ & no & $29.5 \%$ & no & 14915 & no & $1.7 \%$ & no \\
\hline 2 & $16.5 \%$ & no & $18.5 \%$ & no & 9505 & no & $2.1 \%$ & no \\
\hline 3 & $18.0 \%$ & no & $31.5 \%$ & no & 27202 & no & $5.2 \%$ & no \\
\hline 4 & $19.5 \%$ & $29.2 \%$ & $35.5 \%$ & $19.5 \%$ & 683 & 13406 & $5.7 \%$ & $8.6 \%$ \\
\hline 5 & $22.9 \%$ & $22.6 \%$ & $24.7 \%$ & $29.9 \%$ & 0 & 770 & $0.3 \%$ & $23.6 \%$ \\
\hline 7 & no & $28.5 \%$ & no & $27.6 \%$ & no & 0 & no & $19.3 \%$ \\
\hline 8 & $17.3 \%$ & $21.9 \%$ & $56.9 \%$ & $19.5 \%$ & 0 & 0 & $27.3 \%$ & $7.8 \%$ \\
\hline & $18.0 \%$ & $19.9 \%$ & $42.1 \%$ & $20.1 \%$ & 0 & 4389 & $4.5 \%$ & $11.7 \%$ \\
\hline
\end{tabular}

tion as well (see Tab. 3). The proportion of population aged 60 or over is the highest in the Hungarian part of GTK (29.2\%), and it is relatively high in the Slovakian part of the karst, too. On the contrary, the lowest values are found in the valleys \& basins and in the Rudohorie Foothills (16-19\%).

\section{SOCIAL CONDITIONS}

Capturing the degree of socio-economic development is an extremely compound task. However, a crude approximation based on some simple parameters can help us to characterize the situation (Tab. 3). Since there are significant statistical differences between the two countries, we distributed the data not only by landscapes but by countries, too, and it is more reliable to compare numeric values only within countries.

In order to characterize the present economic situation, one can consider the unemployment rate; it is rather high in the Slovakian part of GTK, while it is the lowest in the Hungarian karst area. Thus, these parameters suggest a relatively favorable position of karst in Hungary but a poor situation in Slovakia. Among other factors, it is clearly in connection with tourism.

In the Slovakian part, the most outstanding tourist targets - by the number of accomodation nights - are Rožňava (in 3) and Štós (in 1), the first being a small town with some historical attractions and having a favorable traffic position, the second being a spa resort. As Slovakia has many natural attractions and high mountains (not only in the study area), it seems reasonable that Slovak Karst receives relatively little attention in spite of its karst peculiarities. Meanwhile, the Hungarian part of GTK has an outstanding tourist importance within the study area. While only $5 \%$ of population live in the settlements of Aggtelek Karst, the guest nights show that about three quarter $(72.2 \%)$ of visitors arrive to the karst within the study area (especially to Aggtelek, Jósvafö and Szögliget). In addition, the largest employer in the Aggtelek Karst area is the National Park itself (personal communication by an Aggtelek National Park officer). Nevertheless, even the tourist situation is not at its best. Since the peak in 1978, when 250 thousand people visited the Baradla cave (Fig. 9) the visitor number has gradually decreased with small fluctuations (Tózsa 1996). At present, there are only around 80-90 thousand visitors a year in spite of thorough restorations within the cave and its surroundings recently (Garan 2013). The reasons are multiple. Formerly, a visit to Baradla cave was almost compulsory for school groups, but their number significantly decreased in the last decades. After the change of regime, the whole world became open and the nationwide attractiveness of the cave lose much of its earlier value. A further problem is that most visitors arrive here only for one day that is a significant drawback in terms of tourist revenues (Berecz et al. 2008). As for ecotourism, it has not yet attracted enough tourists, hitherto.

Further on, it should be noted that the unemployment rate is in a moderate relationship $(r=0.46)$ with the proportion of Roma people at the settlement scale. This is a very sensitive situation even politically that is the result of a compound historical social development. Nevertheless, if we try to find some natural elements in this story, we can say that the population of karst terrains with low agricultural potential has always remained at a lower level during history and land properties remained small and in the possession of lower gentry. As a contrary, the Cserehát Hills (5) had slightly better agricultural potential (though its soils are poor and its topography is somewhat dissected) that lead to the formation of large estates where poor serfs worked and immigration was encouraged by landlords (mainly Slovaks and Rusins migrated to the area after the Turkish wars). These poor and mostly Catholic (partly Greek Catholic) people had higher reproduction rates and the area became overpop- 


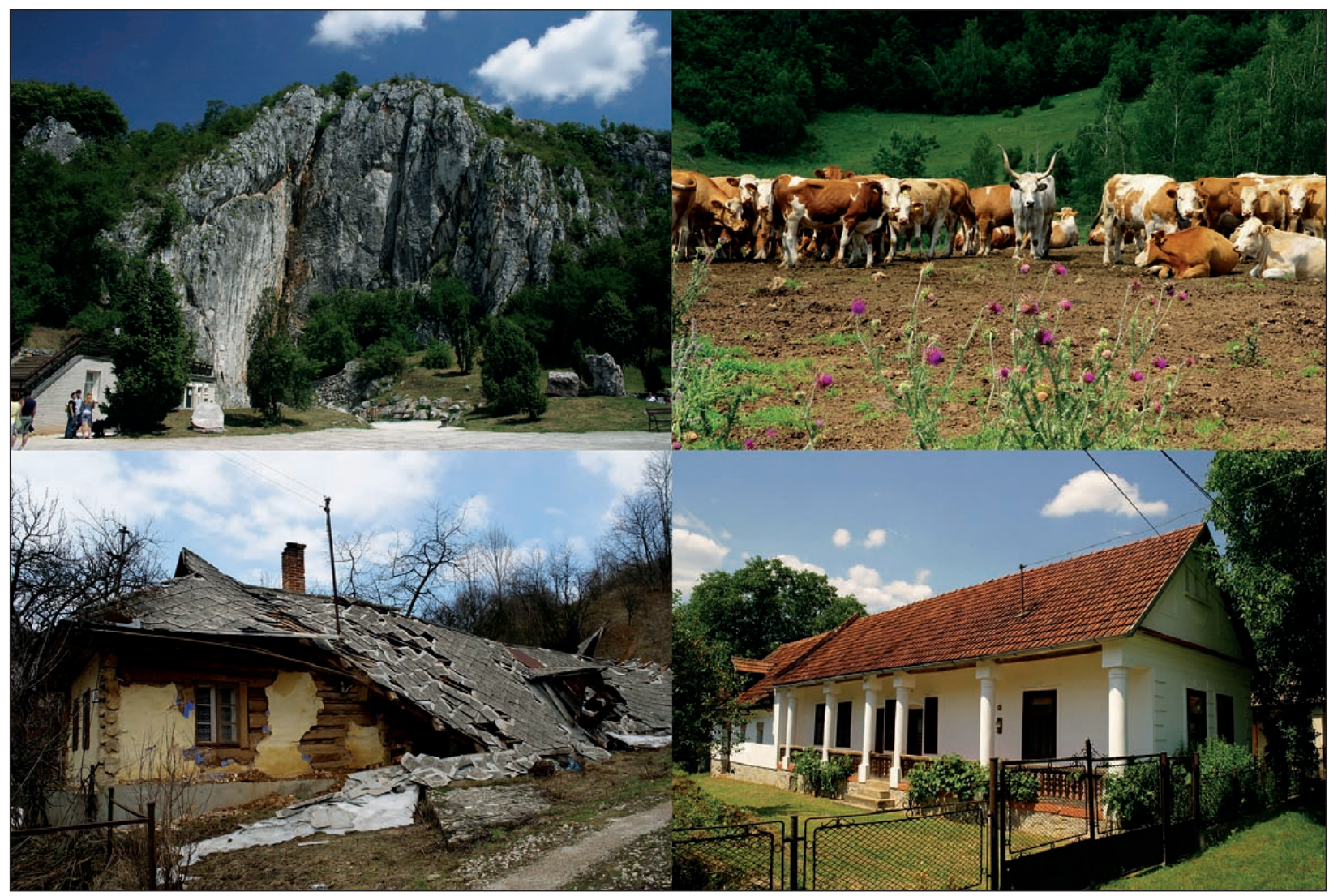

Fig. 9: A) Entry to Baradla cave; B) The last herd on Plešivska plateau; C) Traditional wooden house in ruins in a tiny, dead-end village (Hačava) - a sign of depopulation; D) Restored traditional house in Bódvarákó (All photos: T. Telbisz).

ulated (Dobány 2010a). Due to low life conditions, many people decided to leave the area, especially in the second half of the 20th century. At the change of regime, most of Roma people lost their works in the neighbouring cities and they moved to the cheap and emptying villages without taking over the traditions of the countryside. This lead to the present seriously disadvantageous situation (cf. Beluszky 1979; Molnár 2008). Another hampering effect was, mainly before the change of regime, that this area is found next to the state border which further aggravated its enclosedness.

\section{CHANGING HUMAN ATTITUDE}

The attitude of local people towards natural settings and especially towards karst was examined by semi-structured interviews and field observations. A remarkable change of landuse is the almost total disappereance of pastures as a result of the cease of grazing. Even some decades ago, thousands of sheep and cows were kept mainly on the large, uninhabited and waterless northern karst plateaus (Plešivska, Silicka, Jasovska; Fig. 9) during the summer period, where the animals got water from cisterns. Today, there are only 1-2 shephards, because people do not undertake this harsh way of life even if salaries are ac- ceptable now. Thus, the spreading of forests is typical in the whole karst terrain. The unfavourable arable lands on karst were abandoned even earlier, at the end of the $19^{\text {th }}$ century (Nagy 2006). In the second half of the $20^{\text {th }}$ century most inhabitants of these villages believed that peasants' work (the cultivation of both animals and crops) is only a misery and they intentionally sent their children to towns and cities so that they (the children) have a better life. Further signs of the ageing and depopulating villages are the orchards becoming wild around the settlements. The extending forests' cultivation provide work for few people only.

In the second half of the $20^{\text {th }}$ century, it was a speciality of karst-related settlements that local cavers' clubs provided community and program for the youngs. However, nowadays most young people in these villages desire to be elsewhere, in the large centers and local speleoclubs cease their work, while the ongoing speleo-activities are usually linked to urban people escaping to Nature. Living on a karst area is usually not important in the thought of local people except at Aggtelek and its surroundings. Few people stroll through the karstic hills and mountains and even school children are rarely taken for a visit to karst natural monuments. Based on interviews with mayors we 
can say that environmental thinking is usually not typical in local management, the goal is most often the survival. However, there are some villages where they try to preserve or revive the positive elements of traditional agriculture. Rural tourism and forest schools provide some possibilities for certain villages on the verge of extinction to preserve at least the architectural heritage. Since the human resources are limited in the small, ageing villages, and the present socio-economic conditions are unfamiliar for local people, we observed in many cases that the points of revival are often linked to persons arrived from „outside” (e.g. teacher, priest, national park employee, tourism entrepreneur).

\section{DISCUSSION}

Based on a quantitative global analysis, Small and Cohen (2004) emphasized that population diminishes rapidly with increasing elevation and with increasing distance from coastlines and major rivers. In our local study, we also found that topography and river distance are really strongly influencing factors, but slope is more important than absolute elevation. Our results showing the role of geomorphology in "remoteness” and indirectly in socioeconomic development are in accordance with Milošević et al. $(2010,2011)$, who demonstrated that the unfavourable natural (mainly geomorphological) characteristics are among the key factors in the spontaneous abandonment of settlements in Serbia.

Natural hazards, which are present on many karst terrains (Gutierrez et al. 2014) are less important in GTK partly due to the karst type (e.g. the lack of sudden collapses) partly due to the low economic development (e.g. water quality is good). While many karst landscape conflicts (e.g. deforestation, increase of constructions, water pollution) are in connection with growing population and tourism (e.g. in China, Zhang et al. 2003; Mao et al. 2014), here in the GTK, ageing and depopulation cause significant problems that is similar to other Eu- ropean karstlands (e.g. Velebit Mountains, Pejnović \& Husanović-Pejnović 2008). Arable lands abandoned more than a century ago and pastures unused for several decades are now transformed to forests. It is a conservation issue whether pastures as semi-anthropogenic landscapes should be preserved or not.

Unlike many other karstlands of the world (Duval 2006; Mao et al. 2014), tourism in the GTK is declining since the 1980s, but there are hopes that cross-border cooperation, new strategy, investment and marketing focussing partly on ecotourism may contribute to a new momentum in tourism (Berecz et al. 2008).

As quantitative, landscape-scale studies of the karst and society context are rare, we suggest that further analysis should be performed on other karstlands and a global analysis of population living on karst terrains can be done only after a significant number of local studies get ready. Futher on, another possible way of enlarging these studies is going towards the past using both historical data and environmental proxies (e.g. as Ballut \& Faivre (2012) tried to use doline sediments to infer social changes in the Velebit).

\section{CONCLUSIONS}

The general statement that karsts are relatively rarely inhabited areas with respect to their surroundings was tested and proved to be true for the GTK. The population density differences became even more accentuated during the last two centuries. The population of GTK was stagnant for long then turned to decline during the studied period. However, it is not karst-specific, because the topographically similar, but non-karstic Cserehát Hills have also densely distributed, small and ageing villages. On the other hand, the spatial pattern of settlements is not the same, there is a more uniform distribution in
Cserehát but an uneven distribution in GTK where plateaus are practically uninhabited while foothills are relatively densely populated.

Regression analysis helped to examine the karstspecific effects. The conclusion is that population density and mean settlement population are lower and longterm population change is more negative on karst terrains than it could be expected from the topographic factor only. The other components, namely the land cover (e.g. forests, agriculture) and social parameters (e.g. road density) can be explained solely by the relief parameters. 
The best estimator among relief parameters is usually the slope, while the elevation a.s.l. is the weakest. In case of population density and longterm population change, the river distance proved to be the best estimator.

At present, there are some apparent social differences between GTK and its surroundings. In reality, these differences do not follow strictly the landscape boundaries, instead they are mosaiclike. While incomes are higher and unempleyment is lower in Aggtelek Karst, the demographic situation is the worst. On the other hand, the Slovak Karst has a relatively worse economic position. Further on, the above factors are in correlation with the proportion of Roma people and can not be directly explained by natural settings.

These results outline that while certain natural settings (slope, river distance, karst) have a strong influence on social characteristics, the socio-economic development can not be understood without taking into account human factors as well.

As for tourism, it is quite directly linked to karst terrains within the Hungarian study area. On the con- trary, as Slovak Karst has strong competitors in Slovakia in terms of natural attractions, its tourism is not so emphasized. But even in Hungary, the present development of karst-related tourism is low and it is very localized, observable only around Aggtelek. Thus, it is proposed that tourism should be spatially more distributed. In fact, there are some initiatives for this, but these are not too effective yet. Beside the natural settings of karst, another paradoxical advantage can be mentioned from the viewpoint of tourism: the low development of the area. Due to poverty, the villages escaped the uniformization and modernization of the second half of $20^{\text {th }}$ century, and folk architecture (Fig. 9) has been preserved that has become by now a tourism potential together with the semi-natural landscape. Nonetheless, the preservation of values is difficult without people, that is why it is important to increase the knowledge of the values of karst landscapes in local people and in potential (eco)tourists alike.

\section{ACKNOWLEDGEMENT}

This research has been supported by the Hungarian National Science Foundation, OTKA 104811 project. The work of Tamás Telbisz has been supported by the János Bolyai Scolarship of the Hungarian Academy of Scienc- es. The work of Alena Petrvalská has been supported by the Slovak Research and Development Agency within the project APVV-0176-12.

\section{REFERENCES}

Ballut, C. \& S. Faivre, 2012: New Data On The Dolines Of Velebit Mountain: An Evaluation Of Their Sedimentary Archive Potential In The Reconstruction Of Landscape Evolution.- Acta Carsologica, 41, 1, 59-74.

Bárány-Kevei, I., 1998. Geoecological system of karsts.Acta Carsologica, 27, 13-25.

Barbosa, E. P. \& L. E. P. Travassos, 2008: Caves, Stories, History and Popular Traditions in the Semi-Desert (Sertão) of Bahia, Northeastern Brazil.- Acta Carsologica, 37, 2-3, 331-338.

Barsi, J. (ed.), 2004: Magyarország történeti helységnévtára - Abaúj és Torna vármegye 1773-1808.- KSHBAZ megyei levéltár, pp. 305, Budapest-Miskolc. (in Hungarian)
Beluszky, P., 1979: Borsod-Abaúj-Zemplén megye falusi településeinek típusai. (Types of rural settlements in Borsod-Abaúj-Zemplén County).- Földrajzi Értesítő, 28, 3-4, 339-370. (in Hungarian)

Berecz, B., Füzi, J., Nagy D. \& Zs. Tolnay, 2008: Az Aggteleki-karszt és térsége turisztikai stratégiai és kezelési terve.- Aggtelek National Park, pp. 58, Aggtelek. (in Hungarian)

Cohen, J. E. \& C. Small, 1998: Hypsographic demography: The distribution of human population by altitude. - Proceedings of the National Academy of Sciences of the USA, 95, 14009-14014.

Csorba, Cs. (ed.), 1991: Magyarország történeti helységnévtára - Borsod vármegye 1773-1808.- KSH-BAZ megyei levéltár, pp. 226, Budapest-Miskolc. (in Hungarian) 
Day, M., 2010: Human Interaction With Caribbean Karst Landscapes: Past, Present And Future.- Acta Carsologica, 39, 1, 137-146.

Dénes, Gy., 1998: Történeti áttekintés a XIX. század második feléig. (Historical review to the second half of the 19th century).- In: Baross G. (ed.) Az Aggteleki Nemzeti Park. Mezőgazda Kiadó, pp. 378-395, Budapest. (in Hungarian)

Dobány, Z., 2010a: A Cserehát történeti földrajza, 18-20. század. (Historical Geography of Cserehát, 18-20th century).- ANP Füzetek 8. Aggteleki Nemzeti Park Igazgatóság, pp. 222, Jósvafö. (in Hungarian)

Dobány, Z., 2010b: A Sajó-Bódva köze történeti földrajza, 18-20. század. ((Historical Geography of Sajó-Bódva region, 18-20th century).- ANP Füzetek 9. Aggteleki Nemzeti Park Igazgatóság, pp. 166, Jósvafö. (in Hungarian)

Dövényi, Z. (ed.), 2010: Magyarország kistájainak katasztere. (Cadastre of Small Landscapes of Hungary).MTA Földrajztudományi Kutatóintézet, pp. 876, Budapest. (in Hungarian)

Duval, M., 2006: Tourism And Preservation Policies In Karst Areas: Comparison Between The Škocjan Caves (Slovenija) And The Ardèche Gorge (France).- Acta Carsologica, 35, 2, 23-35.

Erjavec, M. \& M. Peršić, 2005: Living with the lake, living without the lake. An introduction into the research of the way of life by the intermittent karstic lakes Petelinjsko Jezero and Palško Jezero.- Acta Carsologica, 34/3, 10, 784-814.

Fényes, E., 1851: Magyarország geographiai szótára I-II.Kozma-Vazul, Pest. (in Hungarian)

Fürst-Bjeliš, B., Lozić, S. \& D. Perica, 2001: Man and the Environment in the Central Velebit Area - Baške Oštarije and Surroundings.- Acta Geographica Croatica, 35, 111-132.

Garan, B., 2013: Felhívás.- Jósvafői Helytörténeti Füzetek, 38, 4-7. (in Hungarian)

Gutierrez, F., Parise, M., de Waele, J. \& H. Jourde, 2014: A review on natural and human-induced geohazards and impacts in karst.- Earth-Science Reviews, 138, 61-88.

Harden, C. P., 2012: Framing and reframing questions of human-environment interactions.- Annals of the Association of American Geographers, 102, 4, 737-747.

Jékelfalussy, J. (ed.), 1892: A magyar korona országainak helységnévtára.- Pesti Könyvnyomda Rt., Budapest. (in Hungarian)

Kepecs, J. (ed.), 1995: A Felvidék településeinek nemzetiségi (anyanyelvi) megoszlása 1880-1941.- KSH, pp. 656, Budapest. (in Hungarian)
Kepecs, J. (ed.), 1996: A Szlovák Köztársaság településenek nemzetiségi, vallási adatai.- KSH, pp. 367, Budapest. (in Hungarian)

Keveiné Bárány, I., 2014: Landscape Changes In Karsts With Special Regard To Anthropogenic Activity.Karsztfejlödés 19, 5-21. (in Hungarian)

Kiernan, K., 2011: Challenges For Environmentally Sustainable Development Of Natural Resources In The Nam Ou Karst, Northern Laos.- Acta Carsologica, 40, 2, 341-355.

Knez, M. \& T. Slabe, 2010: Karstology and Motorway Construction.- In: Bonacci, O. (ed.) Sustainability of the Karst Environment, Dinaric Karst and other Karst Regions Proceedings, pp. 107-114, UNESCO.

Köszegi, M., Bottlik, Zs., Telbisz, T. \& L. Mari, 2015: Human-Environment Relationships in Modern and Postmodern Geography.- Hungarian Geographical Bulletin (in print)

Lovász, Gy. \& P. Gyenizse, 2012: Impact of karst development on settlement network in Hungary and Croatia.- Karst Development, 2, 1, 21-28.

Majtán, M., 1978: Názvy obcí Slovenskej Republiky (Vyvin $v$ rokoch 1773-1997).- Veda, Bratislava.

Maleković, S., Tišma, S. \& A. Farkaš, 2010: Capacity for managing local development in karst areas.- In: Bonacci, O. (ed.) Sustainability of the Karst Environment. Dinaric Karst and other Karst Regions Proceedings, pp. 129-136, UNESCO.

Mao, X., Meng, J. \& Q. Wang, 2014: Tourism and Land Transformation: A Case Study of the Li River Basin, Guilin, China.- Journal of Mountain Science, 11, 6, 1606-1619.

Meybeck, M., Green, P. \& C. Vörösmarty, 2001: A new typology for mountains and other relief classes: an application to global continental water resources and population distribution.- Mountain Research and Development, 21, 1, 34-45.

Mezősi, G., 1998: A Borsodi-dombság tájföldrajzi jellemzése. (Landscape Geographical Characterization of Borsod Hills).- Földrajzi Értesítő, 47, 3, 395-408. (in Hungarian)

Milanovic, P., 2002: The Environmental Impacts Of Human Activities And Engineering Constructions In Karst Regions.- Episodes, 25, 1, 13-21.

Milošević, M. V., Milivojević, M. \& J. Ćalić, 2010: Spontaneously abandoned settlements in Serbia, Part 1.Journal of the Geographical Institute "Jovan Cvijić" SASA, 60, 2, 39-57.

Milošević, M.V., Milivojević, M. \& J. Ćalić, 2011: Spontaneously abandoned settlements in Serbia, Part 2.Journal of the Geographical Institute "Jovan Cvijić" SASA, 61, 2, 25-35. 
Móga, J., 1998: Természetföldrajzi tényezők hatása a településszerkezetre a Gömör-Tornai-karszt területén. (The impact of phyical geographical factors on settlement structure in Gömör-Torna Karst Area). - In: Frisnyák S. (ed.) A Felvidék történeti földrajza, Nyíregyházi Főiskola, pp. 481-492, Nyíregyháza. (in Hungarian)

Molnár, J., 2008: Cigányok és magyarok életminősége Észak-Csereháton. (Life quality of Romas and Hungarians in the Northern Cserehát Hills). - Földrajzi Értesítő, 57, 3-4, 335-363. (in Hungarian)

Nagy, D., 2006: Reconstruction of Historical Land Use and Land Cover in the Area of Aggtelek National Park and Slovak Karst Biosphere Reserve.- Ökológiai intézet a Fenntartható Fejlődésért Alapítvány, pp. 27, Miskolc. (in Hungarian)

Nagy, L., 1828/29: Notitiae politico-geographico-statisticae Inclyti Regni Hungariae, partiumgue eidem adnexarum, Tom 1-2.- Landrer, Buda.

Parise, M., de Waele, J. \& F. Gutierrez, 2009: Current Perspectives On The Environmental Impacts And Hazards In Karst.- Environmental Geology, 58, 2, 235-237.

Patterson, L. A. \& M. W. Doyle, 2011: Hypsographic demography across scale.- Professional Geographer, $63,4,514-529$.

Pejnović, D. \& D. Husanović-Pejnović, 2008: Causes and consequences of demographic development in the territory of Velebit Nature Park, 1857-2001.- Periodicum Biologorum, 110, 2, 195-204.

Rabus, B., Eineder. M., Roth. A. \& R. Bamler, 2003: The shuttle radar topography mission - a new class of digital elevation models acquired by spaceborne radar.- Photogramm. Rem. Sens., 57, 241-262.

Ravbar, N., 2004: Drinking Water Supply From Karst Water Resources (The Example Of The Kras Plateau, Sw Slovenia).- Acta Carsologica 33, 1, 73-84.

Simić, S., Milovanović B. \& T. Jojić-Glavonjić, 2014: Theoretical Model For The Identification Of Hydrological Heritage Sites.- Carpathian Journal of Earth and Environmental Sciences, 9, 4, 19-30.

Small, C. \& J. E. Cohen, 2004: Continental Physiography, Climate, and the Global Distribution of $\mathrm{Hu}$ man Population.- Current Anthropology, 45, 2, 269-277.
Song, G., Li, Z., Bao, Y., Lü, H., Gao, J., Wang, H., Xu, T. \& Y. Cheng, 2007: Spatial distribution regularity and influence factors of population density in the LRGR.- Chinese Science Bulletin 52, 2, 90-97.

Szabó, J., 1984: A természeti környezet mezőgazdasági szempontú minősítése a Csereháton. (Agricultural Assessment of the Environment in the Cserehát Hills).- Földrajzi Közlemények 32, 3, 255-284. (in Hungarian)

Telbisz, T., 2011: Large-scale relief of the Slovak Karst and Aggtelek Karst (Gömör-Torna/Gemer-Turňa Karst) - a DEM-based study.- Hungarian Geographical Bulletin (Földrajzi Értesítő), 60/4, 379-396.

Telbisz, T., Bottlik, Zs., Mari, L. \& M. Köszegi, 2014: The impact of topography on social factors, a case study of Montenegro.- Journal of Mountain Sciences, 11, 1, 131-141.

Telbisz, T., Bottlik, Zs., Mari, L. \& A. Petrvalská, 2013: Human-environment relations in the Gömör-Torna (Gemer-Turňa) Karst Area and its surroundings.Karsztfejlödés, 18, 137-153.

Telbisz, T., Bottlik, Zs., Mari, L., Petrvalská, A., Kőszegi, M. \& G. Szalkai, 2014: The impact of physical environment on the spatial distribution of population - a case study of Gömör-Torna Karst and its surroundings.- Földrajzi Közlemények, 138, 4, 277-292. (in Hungarian)

Tózsa, I., 1996: Az Aggteleki-karszt idegenforgalmi potenciálja. (The tourism potential of Aggtelek Karst). - Földrajzi Értesítő (Hungarian Geographical Bulletin), 45, 299-314. (in Hungarian)

Turkovics, B. (ed.), 1996: Magyarország történeti statisztikai helységnévtára - Borsod-Abaúj-Zemplén megye 9. Kötet.- KSH, pp. 490, Budapest. (in Hungarian)

Zentai, L. (ed.), 2001: A történelmi Magyarország atlasza és adattára 1914.- Talma kiadó, pp. 247, Pécs. (in Hungarian)

Zhang, C., Day, M. \& W. Li, 2003: Landuse And Land Cover Change In The Lunan Stone Forest, China.Acta Carsologica, 32/2, 13, 161-174. 